\title{
Identification of drought-responsive genes in roots of upland rice
} (Oryza sativa $\mathbf{L}$ )

\author{
Aline R Rabello1,2, Cléber M Guimarães 3 , Paulo HN Rangel3, Felipe R da \\ Silva ${ }^{1}$, Daniela Seixas ${ }^{4}$, Emanuel de Souza ${ }^{4}$, Ana CM Brasileiro ${ }^{1}$, \\ Carlos R Spehar ${ }^{2}$, Márcio E Ferreira ${ }^{1}$ and Ângela Mehta*1
}

Address: ${ }^{1}$ Embrapa Recursos Genéticos e Biotecnologia, PqEB Av W5 Norte Final, CEP 70770-900, Brasília, DF, Brazil, ${ }^{2}$ Universidade de Brasília, CEP 70910-900, Brasília, DF, Brazil, ${ }^{3}$ Embrapa Arroz e Feijão, Rodovia GO-462, km 12 Zona Rural C.P. 179 CEP 75375-000, Santo Antônio de Goiás, GO, Brazil and ${ }^{4}$ Universidade Federal do Paraná, Caixa Postal 19046, CEP 81531-990, Curitiba PR, Brazil

Email: Aline R Rabello - aliner_rabello@yahoo.com.br; Cléber M Guimarães - cleber@cnpaf.embrapa.br;

Paulo HN Rangel - phrangel@cnpaf.embrapa.br; Felipe R da Silva - felipes@cenargen.embrapa.br; Daniela Seixas - dseixas@yahoo.com;

Emanuel de Souza - souzaem@ufpr.br; Ana CM Brasileiro - brasileiro@cenargen.embrapa.br; Carlos R Spehar - spehar@brturbo.com.br; Márcio E Ferreira - ferreira@cenargen.embrapa.br; Ângela Mehta* - amehta@cenargen.embrapa.br

* Corresponding author

Published: 15 October 2008

BMC Genomics 2008, 9:485 doi:10.1/86/147|-2164-9-485
Received: 29 April 2008

Accepted: 15 October 2008

This article is available from: http://www.biomedcentral.com/147I-2/64/9/485

(C) 2008 Rabello et al; licensee BioMed Central Ltd.

This is an Open Access article distributed under the terms of the Creative Commons Attribution License (http://creativecommons.org/licenses/by/2.0), which permits unrestricted use, distribution, and reproduction in any medium, provided the original work is properly cited.

\begin{abstract}
Background: Rice (Oryza sativa L.) germplasm represents an extraordinary source of genes that control traits of agronomic importance such as drought tolerance. This diversity is the basis for the development of new cultivars better adapted to water restriction conditions, in particular for upland rice, which is grown under rainfall. The analyses of subtractive cDNA libraries and differential protein expression of drought tolerant and susceptible genotypes can contribute to the understanding of the genetic control of water use efficiency in rice.

Results: Two subtractive libraries were constructed using CDNA of drought susceptible and tolerant genotypes submitted to stress against CDNA of well-watered plants. In silico analysis revealed 463 reads, which were grouped into 282 clusters. Several genes expressed exclusively in the tolerant or susceptible genotypes were identified. Additionally, proteome analysis of roots from stressed plants was performed and 22 proteins putatively associated to drought tolerance were identified by mass spectrometry.

Conclusion: Several genes and proteins involved in drought-response, as well as genes with no described homologs were identified. Genes exclusively expressed in the tolerant genotype were, in general, related to maintenance of turgor and cell integrity. In contrast, in the susceptible genotype, expression of genes involved in protection against cell damage was not detected. Several protein families identified in the proteomic analysis were not detected in the CDNA analysis. There is an indication that the mechanisms of susceptibility to drought in upland rice are similar to those of lowland varieties.
\end{abstract}




\section{Background}

Rice (Oryza sativa L.) is a cereal of high economic and social value, which is used as a staple food by more than half of the world's population. It is the only cereal which is solely produced for human consumption. The production of rice must increase $20 \%$ in the next 15 years in order to keep pace with population growth. One of the main constraints that affect yield in rice production is water deficit. The increasing worldwide water shortage and uneven rainfall distribution limit the use of irrigated agriculture, typical of rice production. Irrigation costs are increasingly high worldwide. There is, therefore, a need to develop rice varieties, which are more efficient in the use of water $[1,2]$. A major challenge for the research community is the relatively limited progress made so far in improving the drought tolerance of high yielding rice varieties [3].

Rice is a highly diverse species, which can be grown in many types of soil moisture regimes, ranging from aerobic upland to permanently flooded lowland. Although upland rice constitutes a relatively small proportion of the total rice area worldwide, it is the predominant method of rice cultivation in Latin America and West Africa (about $75 \%$ and $50 \%$ of rice area, respectively) [4]. In Brazil, upland rice responds for approximately $40 \%$ of the total rice production. In some areas of the country, upland rice is a subsistence crop planted by farmers who apply limited inputs to their crops. The cultivation of upland rice in marginal areas with low soil fertility and threatened by severe abiotic stresses, such as periods of drought during the cropping season, has a significant impact on rice production $[5,6]$. Due to exposure to many environmental constraints, some local varieties of the tropical japonica rice developed high adaptability to drought stress, hot and dry climatic conditions of regions in Latin America and Africa. Therefore, these varieties may show high levels of water usage efficiency and constitute an excellent material for studying drought tolerance mechanisms in rice. In Brazil, for example, EMBRAPA maintains a germplasm bank enriched with traditional upland rice landraces collected in areas where cultivated rice has been grown since its introduction in the country, centuries ago, and may represent an extraordinary source of genes that control traits of economic importance such as drought tolerance [7].

The determination of the mechanisms directly involved in drought tolerance remains a challenging task since drought is a complex trait that involves several metabolic pathways [3]. The identification and isolation of genes associated with drought tolerance is of major importance in order to better understand this trait and increase the efficiency in developing drought tolerant varieties [8-10]. At the molecular level, the response of roots to water limiting conditions seems to be crucial to trigger drought tolerance mechanisms, since roots are one of the primary sites for stress signal perception in which a signaling mechanism initiates a cascade of gene expression responses to drought. These transcriptional changes can result in successful adaptations leading to stress tolerance by regulating gene expression and signal transduction in the stress response (regulatory proteins) or directly protecting the plant against environmental stress (functional proteins) [11].

Several functional genomic studies of rice have been performed using different approaches such as macro and microarray [12,13], RT-qPCR, SAGE (Serial Analysis of Gene Expression), MPSS (Massive Parallel Signature Sequencing) and more recently oligoarray using the transcriptome of rice to evaluate responses to abiotic stresses [14]. Proteome analyses have also been increasingly employed to complement genomic studies [15-18], however in a lower rate. Although numerous genes and proteins, which potentially contribute to drought tolerance in rice, have been reported [19-22], most of these studies have focused on lowland rice genotypes. Currently, very little is known about gene and protein expression in upland rice [22-25]. Moreover, most ESTs from drought stressed plants available were obtained from libraries constructed using seedlings [26]. There are very few reports on gene expression of drought-stressed plants in the reproductive stage and using root tissue of plants growing under defined field capacity.

The comprehension of drought responses in upland rice is important for designing breeding strategies to develop varieties more tolerant to water constraints. Recently, the tolerance of ten traditional upland varieties of rice submitted to drought stress has been evaluated as part of an effort to identify new sources of drought tolerance in rice [27]. Concomitantly, the root system of two of the above mentioned upland rice genotypes, characterized as susceptible and tolerant to drought stress, have been analyzed at the reproductive stage using genomic and proteomic approaches. Several genes and proteins were identified, which may play important roles in drought tolerance.

\section{Methods \\ I. Plant material and phenotypic evaluation}

Plants of traditional upland rice (O. sativa L. var. japonica) varieties were grown on PVC pipe columns $(25 \mathrm{~cm}$ of diameter; $80 \mathrm{~cm}$ of height) filled with fertilized Oxisol under screenhouse conditions [27]. The experimental design was a split-plot design with two watering regimes as main plots, ten traditional upland varieties as subplots and three replications. The watering regimes were (a) control, consisting of a main plot of well-watered plants throughout the experiment, which received $100 \%$ reposition of the water lost daily and a minimum soil humidity 
of $-0,025 \mathrm{MPa}$ at $15 \mathrm{~cm}$ of depth, and (b) drought stress, which consisted of $50 \%$ reposition of the water lost daily from anthesis on. Water reposition was calculated based on daily weighting of columns with a mechanical scale. Twenty-one days after initiating the drought stress treatment (at anthesis), roots of each treatment (control and drought stress) were collected from each rice variety. All root samples were immediately frozen in liquid nitrogen and maintained at $-80^{\circ} \mathrm{C}$ until their use for RNA and protein extractions. At harvest, grain yield and yield components of each genotype were evaluated, including root and shoot dry weight, harvest index, spikelet sterility, grains per panicle and weight of 100 grains. Drought tolerance parameters were estimated based on calculations of drought severity, drought tolerance index and drought susceptibility index [28]. The genotypes submitted to the drought stress showed differences in most of the yield parameters analyzed, which were significantly influenced by the drought severity applied to the experiment [27]. These parameters were then used to classify the genotypes according to their reaction to stress. Among them, two contrasting genotypes for drought stressing conditions were selected for the present study: Prata Ligeiro, as the tolerant, and IRAT20, as the susceptible variety. The RNA and protein analyses proceeded only with root tissue extracted from these two varieties.

\section{RNA extraction and subtractive library construction}

For each genotype, a bulk of approximately $250 \mathrm{mg}$ of plant roots from the three replications were homogenized in liquid nitrogen and total RNA was extracted using the Concert $^{\mathrm{TM}}$ Plant RNA Reagent (Invitrogen, USA), according to manufacturer's instructions. This procedure was followed for roots harvested from drought stressed as well as unstressed plants. mRNA was then isolated from total RNA by using PolyATtract mRNA Isolation System (Promega, USA). Quantity and quality of the isolated mRNA was evaluated by spectrophotometry and electrophoresis in agarose gel $1 \%$, respectively.

Isolated mRNAs were used for cDNA synthesis and suppression subtractive hybridization (SSH) library construction by using the PCR Select Subtraction Kit (Clontech, USA). Subtractive hybridizations were performed using cDNA from stressed plant roots (as tester) against cDNA from well-watered unstressed plant roots (as driver) of each genotype, in order to identify genes involved in drought response. The subtractive PCR products obtained were cloned into pGEM T-Easy (Promega, USA) and sequenced in ABI Prism 3700 DNA Analyser (Applied Biosystems Inc., USA). A minimum insert size of $30 \mathrm{bp}$ and at least 20 bp with quality of phred $>20$ were considered for the analysis. Sequences were deposited in GenBank under the accession numbers of FG124418 through FG124880 and sequence homologues were identified using the Blast program [29]. An in silico subtraction was performed by clustering all sequences from both cDNA libraries according to the methodology described by Telles and da Silva [30], allowing the identification of genes exclusively found in each library.

\section{Protein extraction and 2-DGE}

Total protein was extracted from roots of the drought tolerant (Prata Ligeiro) and susceptible (IRAT20) genotypes according to procedures described by de Mot and Vanderleyden [31] Plant material of the three replications were pooled, pulverized and mixed with extraction buffer $(0.7$ $M$ sucrose, $0.5 \mathrm{M}$ Tris $\mathrm{HCl}, 30 \mathrm{mM} \mathrm{HCl}, 50 \mathrm{mM}$ EDTA, 0.1 $\mathrm{M} \mathrm{KCl}$ and $40 \mathrm{mM} \mathrm{DTT})$ and phenol (100\%) in the same volume $(750 \mu \mathrm{l})$. Proteins were precipitated with ammonium acetate $0.1 \mathrm{M}$ in methanol, washed with acetone $80 \%(\mathrm{v} / \mathrm{v})$, dried and stored at $-20^{\circ} \mathrm{C}$. Protein quantification was performed using the Bradford Reagent (Invitrogen, USA). Isoelectric focusing was conducted using 11$\mathrm{cm}$ immobilized $\mathrm{pH}$ gradient (IPG) strips with a $\mathrm{pH}$ range of 4-7 and a Multiphor II electrophoresis system (GE). Strips containing approximately $220 \mu \mathrm{g}$ of protein were rehydrated with $2 \%(\mathrm{v} / \mathrm{v}$ ) CHAPS, $8 \mathrm{M}$ urea, $7 \mathrm{mg}$ dithiothreitol (DTT) and 2\% IPG buffer. Second dimension analysis was performed in $10 \%$ gels by SDS-PAGE as described by Laemmli [32] and at least five replications of each genotype were performed. Protein spots were visualized after silver [33] or Comassie blue staining.

\section{Image analysis}

The 2D gel images were evaluated using the Platinum software (GE Healthcare, UK) and three high quality gels obtained for both genotypes were analyzed. First, a calibration with a grey scale was performed to transform grey levels into OD values for each pixel (px) of the gel image. The wizard detection method proposed by the software was used to detect the spots with the following parameters: $15 \mathrm{px}$ for estimated spot size, $50 \mathrm{px}$ for minimum spot size and a spot contrast enhancement of $75 \%$. Automatically detected spots were checked and some of them were manually added or removed. Following the detection procedure, the normalization step was carried out to attribute a common spot identity for the same spots derived from different images utilizing the reference gel construct and automatically matching options. A synthetic gel from each genotype was constructed by using the mean value of volume percentage of each protein spot present in the three replicates, according to the Platinum software's (GE Healthcare, UK) instructions. The two obtained synthetic gels were then overlapped using the molecular marker as well as several protein spots present in both profiles as landmarks. The overlapped images were based on landmark spots showing same $\mathrm{PI}$ and Mw. 


\section{Trypsin digestion and mass spectrometry analysis}

Protein spots were excised manually from 2D gels and ingel digested with sequencing grade trypsin (Promega, Madison, WI) according to Schevchenko et al. [34]. Briefly, each protein spot was placed in a $0.5 \mathrm{~mL}$ polypropylene (Eppendorf) tube and destained by washing 5-8 times with $200 \mu \mathrm{L}$ of $50 \%(\mathrm{v} / \mathrm{v})$ acetonitrile/10 mM ammonium bicarbonate solution. The gel pieces were subsequently dehydrated by washing with $200 \mu \mathrm{L}$ of $100 \%$ acetonitrile and completely dried in a Speedvac concentrator. Ten microliters of $50 \mathrm{mM}$ ammonium bicarbonate $/ 10 \%(\mathrm{v} / \mathrm{v})$ acetonitrile solution containing $100 \mathrm{ng}$ of trypsin were added, and the sample incubated at $37^{\circ} \mathrm{C}$ for $16 \mathrm{~h}$. Aliquots of each tryptic digest $(1 \mu \mathrm{L})$ were mixed with a saturated solution of $\alpha$-cyano-4-hydroxycinnamic acid, spotted onto a MALDI target plate, and allowed to air dry.

Mass spectra were acquired using a MALDI-TOF/TOF Autoflex II spectrometer (Bruker Daltonics, Bremen, Germany) operating at a laser frequency of $50 \mathrm{~Hz}$. MS analysis were performed in a positive ion reflection mode. Voltage parameters were set as IS1 $19 \mathrm{kV}$, IS2 $16.8 \mathrm{kV}$, Lens $8 \mathrm{kV}$, Reflector $20 \mathrm{kV}$, Reflector2 $9.54 \mathrm{kV}$. The delay time was 70 ns and acquisition mass range 700-3200 Da. External calibration was performed using a peptide mix contaning ACTH (1-24), ACTH (18-39), Somatostatin, Angiotensin I and Angiotensin II, all from Sigma. MS/MS analysis were performed in a positive ion LIFT reflection mode. Voltage parameters used were IS1 $6 \mathrm{kV}$, IS2 $5.3 \mathrm{kV}$, lens $3.15 \mathrm{kV}$, Reflector $23.5 \mathrm{kV}$, Reflector2 $9.7 \mathrm{kV}$, LIFT1 $19 \mathrm{kV}$ and LIFT2 $4 \mathrm{kV}$. The delay time was set as zero and acquisition mass range 40-2400 Da.

Peak lists were generated using the FlexAnalysis 3.0 software (Bruker Daltonics). The sophisticated numerical annotation procedure (SNAP) algorithm was used to detect the monoisotopic peak values, with a quality factor threshold of 30 and 6 as S/N threshold. Database searches were performed in February 2008 using the MASCOT search engine (Matrix Science, UK) with the NCBInr protein database and Oryza sativa taxonomy. The mass tolerance was 100 ppm and one missed cleavage was allowed. Carbamidomethylation of cysteines, oxidation of methionine, and acrylamide-modified cysteines were considered for PMF searches. For accepting the identification, the cutoff value for the Probability Based Mowse score calculated by MASCOT (at $p<0.05$ ) was used. For MS/MS data, the peptide mass tolerance was $0.5 \mathrm{Da}, \mathrm{MS} / \mathrm{MS}$ ion mass tolerance at $0.5 \mathrm{Da}$, allowance of 1 missed cleavage, and charge state +1 . When the $\mathrm{pI}$ and $\mathrm{MW}$ of matched proteins were not available, these values were calculated using ExPASy Compute pI/Mw tool http://ca.expasy.org/tools/ pi_tool.html.

\section{Results and discussion \\ I. Experimental design and sampling}

Plants were submitted to drought stress after anthesis for twenty-one days. Flowering is the period in which the plant is most sensitive to water deficit and several tolerance mechanisms need to be activated at this stage in order to guarantee grain filling and production [6]. During root sampling, a clear visual difference in Prata Ligeiro and IRAT20 plants could be observed. An intense leaf rolling was noticed in the susceptible genotype as opposed to the tolerant. In addition, a more pronounced aerial biomass loss could be visualized in IRAT20. At harvest, yield and yield component parameters were measured [27]. The variety IRAT20, a high yielding variety under irrigated controlled conditions, showed a $51 \%$ reduction in grain yield when submitted to drought stress. On the other hand, Prata Ligeiro, a low yielding variety under well watering conditions, had a $23 \%$ reduction in grain yield under drought stress. The drought susceptibility index based on yield was estimated as 0.73 for Prata Ligeiro (tolerant) and 1.57 for IRAT20 (susceptible).

Collected roots of both genotypes were then used for cDNA library construction and proteome studies. In the cDNA library study, stressed plants were contrasted with well-watered plants, whereas in the proteome analysis, stressed plants from both genotypes were compared.

Water reposition, based on the evapotranspiration rate, has been used to determine an impartial and consistent response of plants to drought stress, during long periods of drought in the soil [35]. Several studies have tried to define the critical limit of water in the soil after which crop development and production are significantly affected [36]. According to Rosenthal et al. [37], the symptoms of water deficit occur when water availability is around $50 \%$ of the field capacity.

The response of plants to drought stress is also dependent on the extension and rate of water loss [38]. Fukai et al. [39] reported that when a rapid water deficit occurs, the morpho-physiological mechanisms are severely affected. When the deficit is prolonged for a few days, plants are allowed to adapt to the stress, enabling the identification of variability in drought tolerance within different genotypes, since plants can respond differently to the same stress condition [38]. Therefore, the sampling time used in this study (21 days of drought stress) may have allowed the analysis of adaptive responses of the plant to tolerate water deficit.

Several studies reported the response of rice seedlings to drought stress $[13,26,40]$ however, little attention has been given to the expression of genes in water-stressed 
plants at the reproductive stage (flowering, grain filling) in which a higher yield impact is observed [6].

\section{2. cDNA library analysis}

Roots are one of the primary sites responsive to restrictive conditions of water availability and, as a result, synthesize chemical signals for a rapid response of the plant to drought stress [41]. This occurs since the response in leaves must be stimulated rapidly to avoid irreversible damage to the photosynthetic machinery. In this work, two subtractive cDNA libraries were constructed using mRNA from roots of tolerant and susceptible upland rice genotypes subtracted from their respective unstressed well-watered controls. The subtracted PCR products obtained after primary and secondary PCR ranged from $0,1-1,5 \mathrm{~kb}$.

The SSH libraries of the tolerant (Prata Ligeiro) and susceptible (IRAT20) genotypes were concluded with a novelty index of $66 \%$ and $55 \%$, respectively. The general analysis of the two libraries revealed a total of 463 valid sequences (230 from Prata Ligeiro and 233 from IRAT20) and the average fragment size was of $300 \mathrm{bp}$. Several genes commonly expressed in both genotypes were identified and are probably not directly involved in drought tolerance.

In order to determine the genes exclusively expressed in the tolerant and susceptible genotypes, an in silico subtraction was performed using sequences of both libraries. The results for the in silico subtraction revealed that the 463 sequences represented 282 different transcripts: 127 were found in both genotypes, 84 were exclusively expressed in the Prata Ligeiro library (Table 1 ) and 71 were observed only in the IRAT20 library (Table 2).

\section{I. Putative drought-tolerance genes identified in Prata Ligeiro}

Drought tolerance is a complex trait and involves mechanisms that act in isolation or combined to avoid or tolerate periods of water deficit. It is expected that genotypes responding differently to drought stress show differences in gene expression, and that a portion of the differences is related to drought tolerance. Therefore, the analysis of the genes found exclusively in the tolerant genotype is of interest to identify genes associated with water usage efficiency.

Among the 84 transcripts uniquely reported in the tolerant genotype, 14 did not present known homologs (no hits) and 17 showed similarities to proteins with unknown function (hypothetical proteins). Three sequences showed similarity to non-plant proteins and probably represent contaminating sequences (Table 1). The other transcripts showed similarity to several proteins previously reported as associated to drought stress and some of them are discussed below.

Genes involved in signaling routes were exclusively identified in Prata Ligeiro and include serine/threonine kinase, ethylene-responsive factor and calcium-transporting ATPase/calmodulin binding sequences. Serine/threonine kinases are $\mathrm{Ca}^{2+}$ dependent proteins kinase (CDPKs), involved in the phosphorylation cascade of proteins. Several studies have shown that CDPKs are induced or activated by abiotic stresses, suggesting that they may be involved in drought signaling [42-45]. Another identified gene associated to signal transduction was an ethyleneresponsive factor. Ethylene is a well characterized phytohormone that may act alone or in combination with ABA in regulating gene expression under abiotic stress [46]. Calcium-transporting ATPase/calmodulin binding are also stress-signaling proteins and are responsible for regulation of the osmotic potential of the cell.

Some genes that participate in metabolism alterations as a result of the limitation caused by low levels of intracellular $\mathrm{CO}_{2}$ observed during drought stress were also identified only in Prata Ligeiro. Among these genes are those coding for Phosphoenolpyruvate carboxykinase, an enzyme that has a key role in nocturnal fixation of $\mathrm{CO}_{2}$; malato dehydrogenase, which is an enzyme particularly important for the assimilation of carbon in $\mathrm{C} 4$ plants; Glutamate-1-semialdehyde aminotransferase and glucose-1-fosfato adenililtransferase [47-49], both involved in carbohydrate metabolism.

It has been proposed that the mechanism involved in drought tolerance in upland rice is a result of a higher expression of genes involved in oxidative stress protection [23]. Indeed, in the present study some genes associated to the protection of the cell were expressed only in the tolerant genotype. Among them, we found a Methionine sulfoxide reductase $\mathrm{A}$ and a Respiratory burst oxidase homolog, which act in the recognition of reactive oxygen species (ROS) in biotic and abiotic stresses [50]. Other interesting genes identified are Metallothionein, a superfamily of low molecular weight proteins involved in metal detoxification [51] and scavenging of oxygen-free radicals, which can decrease injury in oxidative tissue, and Ferredoxin, regulated by different environmental stresses including biotic and abiotic conditions.

Genes associated to maintenance of cell turgor were also identified such as IQ calmodulin-binding and Calciumtransporting ATPase/calmodulin binding. These genes were previously reported to participate in typical defense mechanisms in upland varieties [23]. 
Table I: Genes detected exclusively in roots of the tolerant genotype (Prata Ligeiro) SSH library

\begin{tabular}{|c|c|c|}
\hline Encoded protein & Homologous organism & Accession number \\
\hline \multicolumn{3}{|l|}{ Proteins of known function } \\
\hline Glutamate-I-semialdehyde 2,I aminomutase & Oryza sativa & NM 001068872 \\
\hline Metallothionein-like protein & Oryza sativa & NM 001056317 \\
\hline Malate dehydrogenase & Oryza sativa & NM 001062924 \\
\hline Methionine sulfoxide reductase $A$ & Oryza sativa & NM 001063272.1 \\
\hline Phosphatidylinosytol 3 and 4 kinase & Oryza sativa & NM 001060732 \\
\hline Ubiquitin-conjugating enzyme & Oryza sativa & NM 001048429 \\
\hline Nuclear protein SET domain containing protein & Oryza sativa & NM 001067672 \\
\hline Splicing factor 3B subunit 5 -like protein & Oryza sativa & $\overline{\mathrm{db} j|\mathrm{BAD}| 0044.1 \mid}$ \\
\hline PEP carboxikinase & Oryza sativa & $\mathrm{gb} \mid \overline{\mathrm{ABF} 95034.1}$ \\
\hline Putative malate dehydrogenase & Oryza sativa & gb AAT69584.I \\
\hline Eukaryotic translation initiation factor $5 \mathrm{~A}-2$ (elF-5A) (elF-4D) & Oryza sativa & NC 008405 \\
\hline Metallothionein-like protein type I & Oryza sativa & NP 001068544.1 \\
\hline ADP glucose pyrophosphorylase & Oryza sativa & EFI22437 \\
\hline CBL-interacting protein kinase I & Oryza sativa & NM 001049327 \\
\hline ADP-ribosylation factor & Oryza sativa & $\overline{N M} 001051134$ \\
\hline DSSI/SEMI family protein & Oryza sativa & NC 008394 \\
\hline Ankyrin repeat containing protein & Oryza sativa & NM 001054582 \\
\hline Pathogenesis-related transcriptional factor and ERF domain containing protein & Oryza sativa & NC 008402 \\
\hline E-class $\mathrm{P} 450$, group I family protein & Oryza sativa & NM 001074239 \\
\hline FARI domain containing protein & Oryza sativa & NM 001057341 \\
\hline Tubulin alpha-I chain & Oryza sativa & NM 001074145 \\
\hline Putative ubiquitin conjugating enzyme & Oryza sativa & $\overline{d b j|B A B 89662.1|}$ \\
\hline DEAD/DEAH box helicase domain containing protein & Oryza sativa & NM 001069156 \\
\hline Putative pollen specific protein $\mathrm{Cl} 3$ precursor & Oryza sativa & gb|AAM08621.1 \\
\hline IQ calmodulin-binding & Oryza sativa & NM 001061046 \\
\hline HAD superfamily hydrolase 5 ' nucleotidase protein & Oryza sativa & NM 001057956 \\
\hline SAM biding motif domain containing protein & Oryza sativa & NM 001070787 \\
\hline Peptidase aspartic family protein & Oryza sativa & NM 001063168 \\
\hline Nonaspanin (TM9SF) family protein & Oryza sativa & $\overline{\text { NM } 001056027}$ \\
\hline Ethylene responsive element binding factor 5 & Oryza sativa & NM 001063579 \\
\hline TMS membrane protein & Oryza sativa & NM 001054899 \\
\hline Heat shock protein DnaJ family protein & Oryza sativa & NM 001060020 \\
\hline Ferredoxin III, chloroplast precursor (Fd III) & Oryza sativa & NC 008396 \\
\hline Anther ethylene-upregulated protein ERI (Fragment) & Oryza sativa & NM 001055765 \\
\hline Chaperone protein DNA-J-related like & Oryza sativa & $\mathrm{dbj} \mid \mathrm{BAD} 27799.1$ \\
\hline Isoflavone reductase family protein & Oryza sativa & NM 001068997 \\
\hline U box domain containing protein & Oryza sativa & NM 001071339 \\
\hline Ribossomal protein $\mathrm{L}$ & Curculio glandium & AM049038 \\
\hline Short chain dehydrogenase tic 32 & Oryza sativa & NM 001048577 \\
\hline Arabinogalactan protein & Oryza sativa & NC 008394 \\
\hline Ribonuclease $\mathrm{T} 2$ family protein & Oryza sativa & NM 001070328 \\
\hline HvBI2D protein (BI2DgI protein) & Oryza sativa & NM 001063815 \\
\hline Respiratory burst oxidase homolog & Oryza sativa & NM 001049555 \\
\hline Phosphatidylinositol-4-phosphate 5-kinase family protein & Oryza sativa & NM 001068386 \\
\hline Nodulin-like & Oryza sativa & NM 001070322 \\
\hline Cathepsin B-like cysteine protease form 2 & Ixodes ricinus & $\mathrm{gb} \mid \mathrm{ABO} 26563.1$ \\
\hline Cathepsin L-like cysteine proteinase precursor & Acanthoscelides obtectus & $\mathrm{gb} \mid \mathrm{AAQ} 22984.1$ \\
\hline Calcium-transporting ATPase/calmodulin binding & Arabidopsis thaliana & NP 188931.1 \\
\hline Myb, DNA biding domain containing protein & Oryza sativa & NM 001062445 \\
\hline TGA-type basic leucine zipper protein & Phaseolus vulgaris & $\mathrm{gb}|\mathrm{AF} 402607.1|$ \\
\hline Tocopherol O-methyltransferase, choroplast precursor & Oryza sativa & NM 001054379 \\
\hline ATP-dependent Clp protease ATPbiding subunit Clpx-like mitochondrial precursor & Oryza sativa & $\overline{\mathrm{dbj}|\mathrm{BAD}| 58|8.1|}$ \\
\hline $\mathrm{HvB} \mid 2 \mathrm{D}$ protein (BI2DgI protein) & Oryza sativa & NM 001063815 \\
\hline Uncharacterized protein family containing protein & Oryza sativa & $\mathrm{gb}|\mathrm{ABA} 9| 393.1 \mid$ \\
\hline
\end{tabular}

Protein of unknown function

Protein of unknown function

Protein of unknown function 
Table I: Genes detected exclusively in roots of the tolerant genotype (Prata Ligeiro) SSH library (Continued)

\begin{tabular}{|c|c|c|}
\hline Unknow function & Oryza sativa & NM 001067277 \\
\hline Hypothetical protein & Oryza sativa & AP008208 \\
\hline Hypothetical protein & Oryza sativa & gb|EAY93896.1| \\
\hline Conserved hypothetical protein & Oryza sativa & NM 001065538 \\
\hline Hypothetical protein & Oryza sativa & gb|EAY84091.I| \\
\hline Hypothetical protein & Oryza sativa & CT836006 \\
\hline Hypothetical protein & Oryza sativa & NC 008394.I \\
\hline Hypothetical protein & Oryza sativa & NC 008394.1 \\
\hline Hypothetical protein & Oryza sativa & AP008208 \\
\hline Hypothetical protein & Oryza sativa & NM 001057688 \\
\hline Hypothetical protein & Oryza sativa & NM 001066910 \\
\hline Hypothetical protein & Oryza sativa & NM 001053573 \\
\hline Hypothetical protein & Oryza sativa & СТ829595 \\
\hline Hypothetical protein & Oryza sativa & CT834076 \\
\hline
\end{tabular}

In this study we have also identified genes which have not yet been directly related to drought tolerance, such as B12Dg1 protein, Nuclear protein SET domain containing protein and Putative pollen specific protein C13 precursor, as well as genes with unknown function. Further studies need to be performed in order to assign biological function, since these genes may play important roles in plant adaptation during drought stress conditions.

\subsection{Drought-responsive genes identified in IRAT20}

Regarding the response of the susceptible genotype to drought stress, 71 transcripts were exclusively expressed in this genotype. As in Prata Ligeiro, a high number of genes (14) with no known homologs (no hits) were identified (Table 2). Moreover, a total of 23 genes encoding hypothetical or unknown proteins were also observed. Further expression studies of these genes may reveal important genes associated to drought stress response, which have not been explored so far. This information may contribute to a better understanding of the mechanisms related to drought susceptibility in upland rice varieties.

As in Prata Ligeiro, three transcripts showed similarity to non-plant proteins and were not considered in the analysis since they probably represent contaminating sequences (Table 2). The other transcripts showed similarity to genes associated to different functions including the transport of small molecules or inorganic ions, such as $\mathrm{HCO}_{3}$-transporter and Vacuolar $\mathrm{H}+$ pyrophosphatase. The expression of these genes was previously reported by Wang et al. [23] in a lowland variety. These results suggest that upland genotypes susceptible to drought may present similar responses to those of lowland varieties, which are naturally more susceptible to water deficit.

Interestingly, the well-known transcription factor WRKY was uniquely identified in IRAT20. WRKY mediates plant stress responses [52-54] and the increased expression of this protein has been frequently associated to drought stress response in rice $[23,55]$.

\section{Proteome analysis}

In order to complement the genomic studies, protein maps of roots from water-stressed plants of the susceptible (Figure 1A) and tolerant (Figure 1B) genotypes were compared. Triplicates of the gels from each genotype were compared and revealed a total of 463 proteins in the Prata Ligeiro profile and 522 in IRAT20. The two obtained synthetic gels were overlapped and this procedure allowed the identification of 307 overlapped spots, 156 proteins exclusive to the tolerant genotype and 215 proteins exclusive to the susceptible genotype. These results show a higher diversity in the protein pattern of the susceptible genotype.

A total of 50 intense proteins observed in the tolerant genotype profile after Coomassie blue staining was excised from the gel, digested and analyzed by mass spectrometry. By using the Mascot program, 22 proteins could be identified with a significant score (Table 3), including 16 upand 4 down-regulated, 1 new and 1 equally expressed in both genotypes (Figure 2). The other proteins were in insufficient amounts for the identification analysis or did not return reliable matches when using the Mascot program. This probably occurs due to a low protein quantity and/or low ionization capacity of molecular components present in the samples analyzed. It is also possible that, considering the high amount of "no hits" obtained in the genomic analysis, protein sequences matching the peptides searched were not available in public databases. The peptide sequences obtained were also analyzed using the Blastp program.

Spots PL1 and PL2 (up-regulated in Prata Ligeiro) were identified as hypothetical proteins which contain Ricin Brelated lectin domain. Other up-regulated hypothetical proteins were also identified and include protein spots PL34, PL45 and PL51. Spot PL45 and PL51 were expressed 2.6 and 4.5 fold, respectively, in the tolerant genotype (Figure 2), indicating that these proteins may play an important role in drought tolerance. Spot PL57 was 
Table 2: Genes detected exclusively in roots of the susceptible genotype (IRAT20) SSH library

\begin{tabular}{|c|c|c|}
\hline Encoded protein & Homologous organism & Accession number \\
\hline \multicolumn{3}{|l|}{ Proteins of known function } \\
\hline T complex I I family protein & Oryza sativa & NM_00I059402 \\
\hline Protein kinase domain containing protein & Oryza sativa & NM_00107I926 \\
\hline Protein disulphide isomerase family protein & Oryza sativa & AP008208 \\
\hline TPR-like domain containing protein & Oryza sativa & NM_00I058028 \\
\hline Protein kinase & Oryza sativa & NM_00I074788 \\
\hline Pinoresinol-lariciresinol reductase $\mathrm{THI}$ & Oryza sativa & NM_001073059 \\
\hline Smr protein; MutS2 c- terminal domain containing protein & Oryza sativa & NM_00I048992 \\
\hline SIPL protein (Membrane-type I matrix metalloproteinase cytoplasmic tail binding protein-I) & Oryza sativa & NM_00I05558I \\
\hline Similar to CG 9092- PA & Tribolium castanum & XP_967647.I \\
\hline Putative ATP-dependent Clp protease ATP-binding subunit ClpXI (CLPX) & Oryza sativa & dbj|BADI58|8.1| \\
\hline Cytocrome P450 family protein & Oryza sativa & NM_00107I591 \\
\hline Preprotein translocase subunit sec $\mathrm{Y}$, chloroplast precursor & Oryza sativa & NM_001067916 \\
\hline Vacuolar $\mathrm{H}+$ pyrophosphatase & Oryza sativa & NM_00I06350I \\
\hline Similar to UPF 0139 protein $\mathrm{CGI}-140$ & Tribolium castaneum & XP_97|064.II \\
\hline $60 \mathrm{kDa}$ inner membrane insertion protein family protein & Oryza sativa & NM_00I05529I \\
\hline Glyceraldehyde-3-phosphate dehydrogenase (Fragment) & Oryza sativa & NM_001055382 \\
\hline Similar to splicing coativator subunit SRm 300 & Monodelphis domestica & XP_00I37|550.11 \\
\hline Cysteine synthase, mitocondrial precursor & Oryza sativa & NM_001052112 \\
\hline TPR-like domain containing protein & Oryza sativa & NM_00I056953 \\
\hline HCO3-transporter & Oryza sativa & NM_00I07358I \\
\hline Banched chain amino-acid aminotransferase-like protein 3 & Oryza sativa & NM_001049072 \\
\hline Beta tubulin (fragment) & Oryza sativa & NM_00I049296 \\
\hline HAT dimerisation domain containing protein & Oryza sativa & NC_008402 \\
\hline Urease accessory protein G & Oryza sativa & NM_00I062872 \\
\hline Glycoside hydrolase, family 47 protein & Oryza sativa & NM_00I0546I5 \\
\hline WRKY transcription factor 82 & Oryza sativa & DQ298186 \\
\hline Tubby family protein & Oryza sativa & NM_00I062568 \\
\hline Ribosomal protein L4I family protein & Oryza sativa & NC_008400 \\
\hline Granule-bound starch synthase I, chloroplast precursor & Oryza sativa & NM_00I065985 \\
\hline Putative RNA polymerase I transcription factor RRN3 & Oryza sativa & dbj|BAD45608.I| \\
\hline Aconitate hydratase, cytoplasmic (Citrate hydro-lyase) (Aconitase) & Oryza sativa & NM_00I055433 \\
\hline Short chain alcohol dehydrogenase-like & Oryza sativa & NM_001056212 \\
\hline Putative ubiquitin-conjugating enzyme E2 & Oryza sativa & dbj|BAD25096.I| \\
\hline Peptidase s26A signal peptidase I family protein & Oryza sativa & NM_001074823 \\
\hline
\end{tabular}

\section{Protein of unknown function}

Unknown protein

Hypothetical protein

Hypothetical protein

Hypothetical protein

Hypothetical protein

Hypothetical protein

Hypothetical protein

Hypothetical protein

Hypothetical protein

Hypothetical protein

Hypothetical protein

Hypothetical protein

Hypothetical protein

Hypothetical protein

Hypothetical protein

Hypothetical protein

Hypothetical protein

Hypothetical protein

Hypothetical protein

Hypothetical protein

Hypothetical protein

Hypothetical protein

Hypothetical protein
Oryza sativa

Oryza sativa

Oryza sativa

Oryza sativa

Oryza sativa

Oryza sativa

Oryza sativa

Oryza sativa

Oryza sativa

Oryza sativa

Oryza sativa

Oryza sativa

Oryza sativa

Oryza sativa

Oryza sativa

Oryza sativa

Oryza sativa

Oryza sativa

Oryza sativa

Oryza sativa

Oryza sativa

Oryza sativa

Oryza sativa
NM_00I068742

ACI 19292

AP008208

AK243578

NC_008395. I

AP008208

NM_001057104

NC_008395

NM_001074804

NM_001057688

NC_00840I.I

NC_008395. I

CR855II 3

ACI 45477

AC092556

AK242616

AP008209

NC_008398. I

AC09940I

NM_001050487

CT831698

CT828847

CT832865 
another protein identified as hypothetical and was exclusively expressed in Prata Ligeiro. These proteins are interesting candidates for futures studies aiming at the determination of biological function.

Spots PL3 and PL60 were identified as the same protein chitinase and spot PL11 as a Chain A, Crystal Structure of Class I Chitinase. Chitinases are pathogenesis-related proteins expressed in response to biotic and abiotic stresses and have been studied in grasses such as rye in response to cold and drought stress [56]. Spot PL60 was highly induced in the tolerant genotype, which confirms the upregulation of this protein during drought stress. Chitinases have also been reported as being induced in tomato plants tolerant to drought when compared to the susceptible genotype [57].

Two other pathogenesis-related proteins were identified: one was up-regulated (spot PL33) and the other repressed (PL30) in the tolerant genotype (Figure 2). The expression of these proteins has been previously reported in roots of rice in drought stress conditions and although the role of proteins of this family is not well established, they have been associated to hypersensitive reaction in response to biotic and abiotic factors [58]. In drought stress conditions, pathogenesis-related proteins as well as the salt stress-responsive SalT protein have been reported in rice roots [59].

As observed in the constructed cDNA libraries, several proteins involved in oxidative stress protection were induced in the tolerant genotype and were identified as a superoxide dismutase [Cu-Zn] (PL20), L- ascorbate peroxidase 1 (PL23), ascorbate peroxidase (PL38) and cytosolic malate dehydrogenase (PL63) (Table 3). Peroxidases are anti-oxidative enzymes, described in varieties of rice tolerant to high salinity conditions $[25,60]$ and in upland rice roots in response to osmotic stress [24]. These proteins are involved in cellular detoxification and it is possible that this is a general defense mechanism in response to water deficit in upland rice. According to Wang et al. $[23,24]$ tolerance to drought stress observed in upland varieties includes detoxification mechanisms, limiting the accumulation of reactive oxygen species. These authors reported that these proteins were up-regulated in upland cultivars when comparing tolerant lowland and upland rice. Unexpectedly, proteins identified as superoxide dismutase (PL7) and GSH-dependent dehydroascorbate reductase (PL13) were down-regulated in the tolerant genotype. These proteins were not identified in the genomic analysis, highlighting the importance of proteomics studies to complement the results obtained.

Another down-regulated protein (PL24) identified in the Prata Ligeiro genotype was triosephosphate isomerase
(Table 3), involved in carbohydrate metabolism. According to Wang et al. [23], genes related to metabolism are more expressed in lowland than in upland genotypes. It is possible that susceptibility to drought in upland rice may occur in a similar way as in lowland rice.

Spots PL43 and PL46 were both identified as enolase, a glycolytic enzyme, which participates in metabolic processes. The up-regulation of enolase has been previously reported in rice roots in response to salt stress [61] and to PEG treatment [24]. Unexpectedly, PL46 was equally expressed in Prata Ligeiro and IRAT20, while spot PL43 was up-regulated in Prata Ligeiro. The existence of multiple enolase isoforms in plants has been reported [62] and it is possible that the enolases identified in this study represent different isoforms, which respond differently to drought stress conditions. Indeed, difference in the expression of enolase isoforms was observed in maize in response to anaerobiosis [63].

A highly induced protein (15 fold) in the tolerant genotype (PL40) showed identity to a hypothetical protein as well as a salt stress induced protein (Table 3). Similarly, spot 27 (2.6 fold higher in Prata Ligeiro) also presented identity to the salt stress induced protein. It is possible that these spots represent new rice proteins, not identified so far that contain a conserved region present in both matching proteins. The induction of proteins involved in tolerance to salt stress, during water deficit conditions, shows that osmotic stress is an important aspect during drought. Similar mechanisms are activated in response to different abiotic stresses, as previously reported [10].

\section{Conclusion}

Several genes and proteins involved in drought-response as well as genes with no described homologs were identified in this work. Genes exclusively expressed in the tolerant genotype were, in general, related to maintenance of turgor and cell integrity. In contrast, in the susceptible genotype, expression of genes involved in protection against cell damage was not detected, indicating that there may be a higher degradation of cellular components in these genotypes. Similar results were obtained by Wang et al. [23] when comparing tolerant upland and lowland varieties. These results indicate that the mechanisms of susceptibility in upland rice are similar to those of lowland varieties, considering that the upland rice is naturally more tolerant to drought stress.

The proteomic analyses were complementary to the genomic data obtained. The expression of genes associated with cell protection against oxidative damage is considered important to cope with water deficit in upland rice. In this study, genes and proteins related to this function showed a higher expression in the tolerant genotype. 

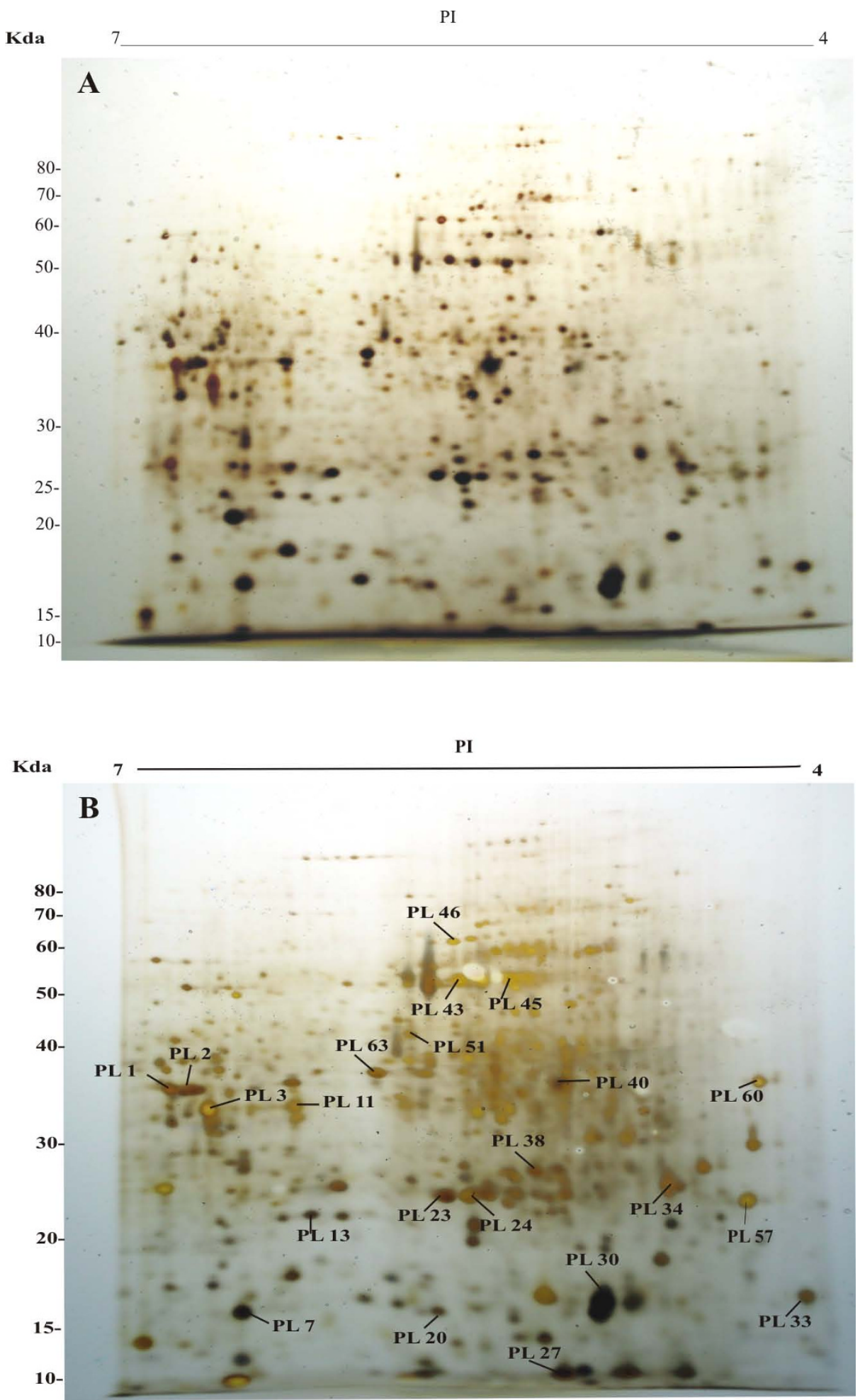

Figure I

Root protein profiles by 2-DGE of the susceptible (A) and tolerant (B) genotypes. Total soluble protein (ca. $220 \mu \mathrm{g})$ was separated by 2-DGE and the spots were visualized after silver staining. Numbers indicate the protein spots successfully identified by mass spectrometry. Benchmark Protein Ladder (Invitrogen, USA) was used to estimate the molecular mass of the proteins visualized. 


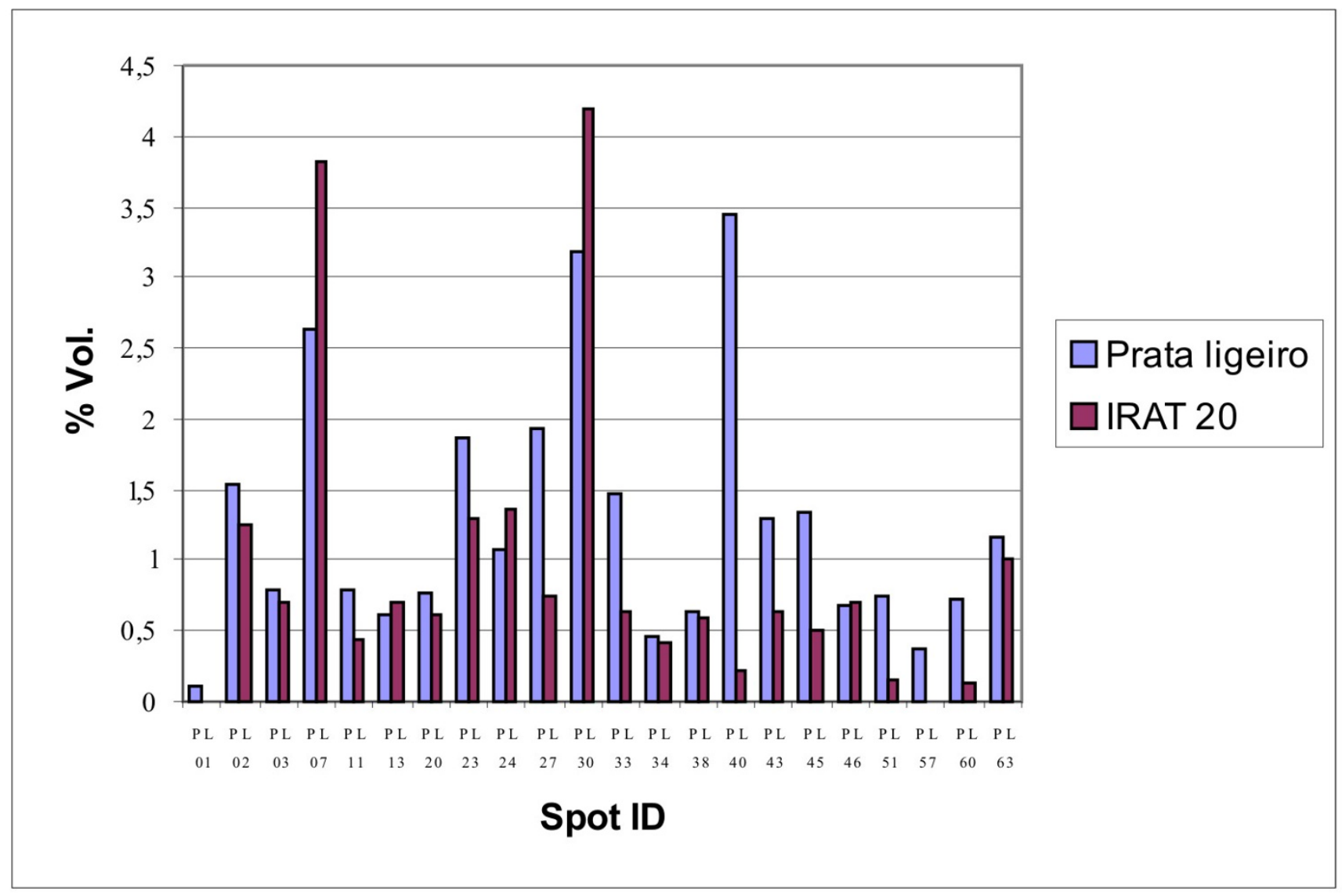

Figure 2

Histogram representing expression levels of up- and down-regulated proteins identified in the tolerant (Prata Ligeiro) and susceptible (IRAT20) genotypes, as determined by the Platinum software (GE Healthcare, UK).

Interestingly, in the proteomics analysis, the susceptible genotype showed a higher diversity in the protein profile, revealing more uniquely expressed proteins than the tolerant genotype. On the other hand, in the genomic study, the number of exclusively expressed transcripts in the susceptible genotype was lower. It is well known that transcript levels do not always reflect protein amounts $[64,65]$. Therefore, it is possible that the transcripts related to the proteins exclusively present in IRAT20 2D maps were in low amounts, and not detected by the genomic analysis, or they were subtracted from the control condition in the hybridization process. Differences in translation efficiency may have occurred, resulting in a higher amount of the corresponding proteins, further detected by 2-DGE. These results clearly show that proteomics studies can reveal important additional information and that the use of complementary approaches is useful for a better understanding of complex biological traits, such as drought tolerance.
Overall, due to the low amount of information regarding upland rice gene and protein expression in response to water deficit, this study sheds some light over the comprehension of this complex mechanism. However, the high amount of transcripts and proteins with unknown function obtained is still intriguing. These genes and proteins need to be further investigated in order to assign their biological function and advance our knowledge regarding drought tolerance in upland rice.

\section{Authors' contributions}

AM, ARR, CMG, MEF and PHNR designed and performed the research. FRS analyzed the sequence data and EMS and DS analyzed the mass spectrometry data. ARR and AM drafted the manuscript. ACMB and CRS critically revised the article. All authors approved the final version.

\section{Acknowledgements}

This research was supported by Embrapa, CNPq and Embrapa Recursos Genéticos e Biotecnologia. 
Table 3: Proteins identified by peptide mass fingerprinting or de novo sequencing

\begin{tabular}{|c|c|c|c|c|c|c|c|c|}
\hline Spot $n^{\circ}$ & Peptide sequence & Protein identification & Accession \# & Score & Mr (gel) & pl (gel) & Mr (cal) & pl (cal) \\
\hline PL I & & Hypothetical protein & gi| I I5452789 & 138 & 38.0 & 6,7 & 39 & 6.3 \\
\hline PL2 & & Hypothetical protein & gi| I I5452789 & 65 & 39.0 & 6.6 & 39 & 6.3 \\
\hline PL 3 & WAPSPADAAAGR & Chitinase & gi|407472 & 56 & 36.0 & 6.6 & 35.5 & 7.3 \\
\hline PL 7 & EHGAPQDENR & Zinc-superoxide dismutase & gi|222296339 & 26 & 15.0 & 6.4 & 14.7 & 5.9 \\
\hline PL II & GPIQLSFNFNYGPAGR & $\begin{array}{l}\text { Chain A, Crystal Structure Of } \\
\text { Class I Chitinase }\end{array}$ & $\mathrm{pdb}|2 \mathrm{DKV}| \mathrm{A}$ & 30 & 37.0 & 6.2 & 32.6 & 5.8 \\
\hline PL 13 & AAVGHPDTLGDCPFSQR & $\begin{array}{l}\text { GSH-dependent } \\
\text { dehydroascorbate reductase I }\end{array}$ & gi|6939839 & 43 & 26.0 & 6.1 & 23.5 & 5.6 \\
\hline PL 20 & $\begin{array}{l}\text { GTSQVEGVVTLTQDDQGP } \\
\text { TTVNVR }\end{array}$ & $\begin{array}{l}\text { Putative superoxide dismutase } \\
\text { [Cu-Zn] }\end{array}$ & gi|42408425 & 72 & 17.0 & 5.5 & 20.5 & 5.7 \\
\hline PL 23 & & L-ascorbate peroxidase I, & P93404 & 99 & 28.0 & 5.5 & 27 & 5.4 \\
\hline PL 24 & VATPDQAQEVHDGLR & Triosephosphate isomerase & gi| 553107 & 49 & 28.0 & 5.4 & 27.5 & 6.6 \\
\hline PL 27 & EFSIPLQDSGHVVGFFGR & Salt stress-induced protein & gi| $\mid 585$ I 3205 & 88 & 11.0 & 5.0 & 15.1 & 5.1 \\
\hline PL 30 & MIEDYLVAHPAEYA & $\begin{array}{l}\text { Pathogenesis-related protein Bet } \\
\text { v I }\end{array}$ & gi|9230755 & 55 & 18.0 & 4.9 & 16.6 & 4.9 \\
\hline PL 33 & $\begin{array}{l}\text { ADVGVGPVSWDDTVAAY } \\
\text { AESYAAQR }\end{array}$ & $\begin{array}{l}\text { Acidic PR-I type pathogenesis- } \\
\text { related protein PR-I }\end{array}$ & gi| $\mid 2005673$ & 182 & 17.5 & 4.2 & 17.5 & 4.5 \\
\hline PL34 & WWDTFPANVDGAR & Hypothetical protein & gi| II I546I070 & 87 & 29.0 & 4.7 & 27.2 & 5.0 \\
\hline PL 38 & & Ascorbate peroxidase & NP_00I06074I & 74 & 32.0 & 5.2 & 27 & 5.2 \\
\hline PL 43 & $\begin{array}{l}\text { MTAEIGEQVQIVGDDLLVT } \\
\text { NPTR }\end{array}$ & Enolase & gi|780372 & 88 & 60.0 & 5.4 & 47.9 & 5.4 \\
\hline PL 46 & & Enolase & Q4297I & 74 & 50.0 & 5.4 & 47.9 & 5.4 \\
\hline PL 45 & & Hypothetical protein & gi|II I5465323 & 98 & 60.0 & 5.2 & 58.8 & 5.9 \\
\hline PL 5I & KADATVAGDDR & Hypothetical protein & gi| $\mid 25557770$ & 37 & 45.0 & 5.7 & 95.7 & 8.0 \\
\hline PL 57 & AGYAPPHWVQPGQGDR & Hypothetical protein & gi| $|25532459|$ & 73 & 25.0 & 4.2 & 24.5 & 4.6 \\
\hline PL 60 & ELFEQLLLHR & Chitinase & gi|561873 & 51 & 36.5 & 4.2 & 34.3 & 4.4 \\
\hline PL 63 & $\begin{array}{l}\text { ELVADDEWLNTEFISTVQQ } \\
\mathrm{R}\end{array}$ & Cytosolic malate dehydrogenase & gi| II 5482534 & 66 & 37.5 & 5.9 & 35.5 & 5.75 \\
\hline \multirow[t]{2}{*}{ PL 40} & EFSIPLQDSGHVVGFFGR & Salt stress-induced protein & gi| $1585 \mid 3205$ & 104 & 39 & 5.3 & 15.1 & 5.1 \\
\hline & & Hypothetical protein & EAY73933 & & & & 40.6 & 8.6 \\
\hline
\end{tabular}

\section{References}

I. Luo LJ, Zhang QF: The status and strategy on drought resistance of rice (Oryza sativa L.). Chin J Rice Sci 200I, I 5:209-2 I4.

2. Liu H, Mei H, Yu X, Zou G, Liu G, Luo L: Towards improving the drought tolerance of rice in China. Plant Genet Resour 2007, 4(0I):47-53.

3. Price $A H$, Cairns JE, Horton P, Jones HG, Griffiths $\mathrm{H}$ : Linking drought-resistance mechanisms to drought avoidance in upland rice using a QTL approach: progress and new opportunities to integrate stomatal and mesophyll responses. J Exp Bot 2002, 53(37I):989-1004.

4. Gupta PC, O'Toole JC: Upland rice: a global perspective. Los Baños, Laguna: IRRI; I 986.

5. Pinheiro B da S, de Castro E da M, Guimarães CM: Sustainability and profitability of aerobic rice production in Brazil. Field Crops Res 2006, 97(I):34-42.

6. Heinemann A, Dingkuhn M, Luquet D, Combres J, Chapman S: Characterization of drought stress environments for upland rice and maize in central Brazil. Euphytica 2007, I62(3):395-410.

7. Pessoa-Filho M, Beló A, Alcochete AAN, Rangel PHN, Ferreira ME: A set of multiplex panels of microsatellite markers for rapid molecular characterization of rice accessions. BMC Plant Biol 2007, 7:23-23.

8. Tuberosa R, Salvi S: Genomics-based approaches to improve drought tolerance of crops. Trends Plant Sci 2006, I I (8):405-4I 2.

9. Lafitte HR, Yongsheng G, Yan S, Li ZK: Whole plant responses, key processes, and adaptation to drought stress: the case of rice. J Exp Bot 2007, 58(2): 169-175.

10. Sreenivasulu N, Sopory SK, Kavi Kishor PB: Deciphering the regulatory mechanisms of abiotic stress tolerance in plants by genomic approaches. Gene 2007, 388(I-2): I-13

II. Périn C, Rebouillat J, Brasileiro ACM, Diévart A, Gantet P, Breitler JC, Johnson AAT, Courtois B, Ahmadi N, de Raissac M, et al.: Novel insights into the genomics of rice root adaptive development. In Rice Genetics V Edited by: Brar DS, Mackill DJ, Hardy B. Singapore: World Scientific; 2007:I 17-I4I.

12. Kawasaki S, Borchert C, Deyholos M, Wang H, Brazille S, Kawai K, Galbraith D, Bohnert H]: Gene expression profiles during the initial phase of salt stress in rice. The Plant Cell 200I, 13(4):889-905.

13. Rabbani MA, Maruyama K, Abe H, Khan MA, Katsura K, Ito Y, Yoshiwara K, Seki M, Shinozaki K, Yamaguchi-Shinozaki K: Monitoring expression profiles of rice genes under cold, drought, and high-salinity stresses and abscisic acid application using cDNA microarray and RNA gel-blot analyses. Plant Physiol 2003, I33(4): 1755-1767.

14. Yamaguchi-Shinozaki K, Shinozaki K: Transcriptional regulatory networks in cellular responses and tolerance to dehydration and cold stresses. Annu Rev Plant Biol 2006, 57:78I-803.

15. Salekdeh GH, Siopongco J, Wade LJ, Ghareyazie B, Bennett J: Proteomic analysis of rice leaves during drought stress and recovery. Proteomics 2002, 2(9): $1|3|-|| 45$.

16. Salekdeh GH, Siopongco J, Wade LJ, Ghareyazie B, Bennett J: A proteomic approach to analyzing drought- and salt-responsiveness in rice. Field Crops Res 2002, 76(2-3):199-219.

17. Agrawal GK, Jwa NS, Iwahashi Y, Yonekura M, Iwahashi H, Rakwal R: Rejuvenating rice proteomics: Facts, challenges, and visions. Proteomics 2006, 6(20):5549-5576.

18. Agrawal GK, Rakwal R: Rice proteomics: A cornerstone for cereal food crop proteomes. Mass Spectrom Rev 2006, 25(I): I-53.

19. Yang L, Zheng B, Mao C, Qi X, Liu F, Wu P: Analysis of transcripts that are differentially expressed in three sectors of the rice root system under water deficit. Mol Genet Genomics 2004, 272(4):433-442. 
20. Fu BY, Xiong JH, Zhu LH, Zhao XQ, Xu HX, Gao YM, Li YS, Xu JL, $\mathrm{Li} Z \mathrm{ZK}$ : Identification of functional candidate genes for drought tolerance in rice. Mol Genet Genomics 2007, 278(6):599-609.

21. Gorantla M, Babu PR, Lachagari VBR, Reddy AMM, Wusirika R, Bennetzen JL, Reddy AR: Identification of stress-responsive genes in an indica rice (Oryza sativa L.) using ESTs generated from drought-stressed seedlings. J Exp Bot 2007, 58(2):253-265.

22. Wu C-Q, Hu H-H, Zeng Y, Liang D-C, Xie K-B, Zhang J-W, Chu Z$H$, Xiong L-Z: Identification of Novel Stress-responsive Transcription Factor Genes in Rice by cDNA Array Analysis. J Integr Plant Biol 2006, 48( I 0): I $216-1224$.

23. Wang $\mathrm{H}$, Zhang $\mathrm{H}$, Gao F, Li J, Li Z: Comparison of gene expression between upland and lowland rice cultivars under water stress using cDNA microarray. Theor Appl Genet 2007, I I 5(8): I I09- I I 26.

24. Wang H, Zhang H, Li Z: Analysis of Gene Expression Profile Induced by Water Stress in Upland Rice (Oryza sativa L. var. IRAT I09) Seedlings using Subtractive Expressed Sequence Tags Library. J Integr Plant Biol 2007, 49( I 0): | 455 - | 463.

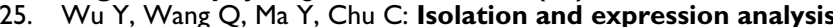
of salt up-regulated ESTs in upland rice using PCR-based subtractive suppression hybridization method. Plant Sci 2005 , I 68(3):847-853.

26. Reddy AR, Ramakrishna W, Sekhar AC, Ithal N, Babu PR, Bonaldo $M F$, Soares MB, Bennetzen JL: Novel genes are enriched in normalized cDNA libraries from drought-stressed seedlings of rice (Oryza sativa L. subsp. indica cv. Nagina 22). Genome 2002, 45(I):204-2II.

27. Guimarães CM, Stone LF, Rangel PHN, Ferreira ME, Rodrigues CAP. Resistência à seca: III. Avaliação do sistema radicular do arroz de terras em condições controladas. In Anais do II Congresso da Cadeira Produtiva de Arroz e Reunião Nacional de Pesquisa de Arroz Brasília, DF. Embrapa, SPI; 2006.

28. Fischer RA, Maurer R: Drought resistance in spring wheat cultivars. I. Grain yield responses. Aust J Agric Res I978, 29:897-9I 2.

29. Altschul SF, Madden TL, Schäffer AA, Zhang J, Zhang Z, Miller W, Lipman DJ: Gapped BLAST and PSI-BLAST: a new generation of protein database search programs. Nucleic Acids Res 1997, 25(I 7):3389-3402.

30. Telles GP, Silva FR: Trimming and clustering sugarcane ESTs. Genet Mol Biol 200I, 24(1-4): I7-23.

31. De Mot R, Vanderleyden J: Application of two-dimensional protein analysis of strain fingerprinting and mutant analysis of Azospirillum species. Can J Microbiol I 989, 35( I 0):960-967.

32. Laemmli UK: Cleavage of structural proteins during the assembly of the head of bacteriophage T4. Nature 1970, 227(5259):680-685

33. Blum $\mathrm{H}$, Beier $\mathrm{H}$, Gross $\mathrm{HJ}$ : Improved silver staining of plant proteins, RNA and DNA in polyacrylamide gels. Electrophoresis 1987, 8(2):93-99.

34. Shevchenko A, Wilm M, Vorm O, Mann M: Mass spectrometric sequencing of proteins silver-stained polyacrylamide gels. Anal Chem 1996, 68:850-858.

35. Sinclair TR, Ludlow MM: Influence of Soil Water Supply on the Plant Water Balance of Four Tropical Grain Legumes. Funct Plant Biol I 986, I3(3):329-34I.

36. Grant RF, Jackson BS, Kiniry JR, Arkin GF: Water Deficit Timing Effects on Yield Components in Maize. Agron J 1989 8I(I):6I-65.

37. Rosenthal WD, Arkin GF, Shouse PJ, Jordan WR: Water Deficit Effects on Transpiration and Leaf Growth. Agron J 1987 79(6): $1019-1026$.

38. Bray EA: Plant responses to water deficit. Trends Plant Sci 1997, 2(2):48-54.

39. Fukai S, Cooper M: Development of drought-resistant cultivars using physiomorphological traits in rice. Field Crops Res 1995 40(2):67-86.

40. Agarwal S, Grover A: Isolation and transcription profiling of low-O2 stress-associated cDNA clones from the floodingstress-tolerant FRI3A rice genotype. Ann Bot 2005 , 96(5):831-844.

4l. Wilkinson S, Davies W]: ABA-based chemical signalling: the coordination of responses to stress in plants. Plant Cell Environ 2002, 25(2): 195-210.

42. Hwang I, Sze H, Harper JF: A calcium-dependent protein kinase can inhibit a calmodulin-stimulated Ca2+ pump (ACA2) located in the endoplasmic reticulum of Arabidopsis. Proc Natl Acad Sci USA 2000, 97(I I):6224-6229.

43. Pei ZM, Ward JM, Harper JF, Schroeder JI: A novel chloride channel in Vicia faba guard cell vacuoles activated by the serine/ threonine kinase, CDPK. EMBO J 1996, I 5(23):6564-6574.

44. Tähtiharju S, Sangwan V, Monroy AF, Dhindsa RS, Borg M: The induction of kin genes in cold-acclimating Arabidopsis thaliana. Evidence of a role for calcium. Planta 1997, 203(4):442-447.

45. Urao T, Katagiri T, Mizoguchi T, Yamaguchi-Shinozaki K, Hayashida $\mathrm{N}$, Shinozaki K: Two genes that encode $\mathrm{Ca}(2+)$-dependent protein kinases are induced by drought and high-salt stresses in Arabidopsis thaliana. Mol Gen Genet 1994, 244(4):33 I-340.

46. Xiong L, Schumaker KS, Zhu J-K: Cell signaling during cold, drought, and salt stress. Plant Cell 2002, I4(Suppl):SI65-SI83.

47. Chollet R, Vidal J, O'Leary MH: Phosphoenolpyruvate Carboxylase: A ubiquitous, highly regulated enzyme in plants. Annu Rev Plant Physiol Plant Mol Biol 1996, 47:273-298.

48. Nimmo GA, Nimmo HG, Hamilton ID, Fewson CA, Wilkins MB: Purification of the phosphorylated night form and dephosphorylated day form of phosphoenolpyruvate carboxylase from Bryophyllum fedtschenkoi. Biochem J I986, 239(I):213-220.

49. Vidal J, Chollet R: Regulatory phosphorylation of C4 PEP carboxylase. Trends in Plant Sci 1997, 2(6):230-237.

50. Torres MA, DangI JL: Functions of the respiratory burst oxidase in biotic interactions, abiotic stress and development. Curr Opin Plant Biol 2005, 8(4):397-403.

5I. Kägi JH, Schäffer A: Biochemistry of metallothionein. Biochemistry 1988, 27(23):8509-85I5.

52. Eulgem T, Rushton PJ, Robatzek S, Somssich IE: The WRKY superfamily of plant transcription factors. Trends Plant Sci 2000, 5(5): $199-206$

53. Ross CA, Liu Y, Shen Q]: The WRKY Gene Family in Rice (Oryza sativa). J Integr Plant Biol 2007, 49(6):827-842.

54. Ulker B, Somssich IE: WRKY transcription factors: from DNA binding towards biological function. Curr Opin Plant Biol 2004, 7(5):49|-498.

55. Qiu YP, Jing SJ, Fu J, Li L, Yu DQ: Cloning and analysis of expression profile of 13 WRKY genes in rice. Chin Sci Bull 2004, 49(20):2159-2168.

56. $\mathrm{Yu} X-\mathrm{M}$, Griffith M, Wiseman SB: Ethylene Induces Antifreeze Activity in Winter Rye Leaves. Plant Physiol 2001, I26(3): I 232- 1240.

57. Yu LX, Djebrouni M, Chamberland $\mathrm{H}$, Lafontaine JG, Tabaeizadeh Z: Chitinase: Differential induction of gene expression and enzyme activity by drought stress in the wild (Lycopersicon chilense Dun.) and cultivated ( $L$. esculentum Mill.) tomatoes. J Plant Physiol 1998, I 53(5-6):745-753.

58. Liu Q, Xue Q: Molecular Phylogeny, Evolution, and Functional Divergence of the LSDI-Like Gene Family: Inference from the Rice Genome. J Mol Evol 2007, 64(3):354-363.

59. Moons A, Prinsen E, Bauw G, Montagu MV: Antagonistic effects of abscisic acid and jasmonates on salt stress-inducible transcripts in rice roots. Plant Cell 1997, 9( I 2):

60. Mittal R, Dubey RS: Behaviour of peroxidases in rice: changes in enzyme activity and isoforms in relation to salt tolerance. Plant Physiol Biochem I991, 29(I):31-40.

6I. Yan S, Tang Z, Su W, Sun W: Proteomic analysis of salt stressresponsive proteins in rice root. Proteomics 2005, 5(I):235-244.

62. van der Straeten D, Rodrigues-Pousada RA, Goodman HM, van Montagu M: Plant enolase: gene structure, expression, and evolution. Plant Cell 1991, 3:719-735.

63. Lal SK, Lee C, Sachs MM: Differential regulation of enolase during anaerobiosis in maize. Plant Physiol I 998, I I 8(4): I 285-I 293.

64. Jones AME, Thomas V, Truman B, Lilley K, Mansfield J, Grant M: Specific changes in the Arabidopsis proteome in response to bacterial challenge: differentiating basal and R-gene mediated resistance. Phytochemistry 2004, 65(1 2): I805-1816.

65. Lian H-L, Yu X, Lane D, Sun W-N, Tang Z-C, Su W-A: Upland rice and lowland rice exhibited different PIP expression under water deficit and ABA treatment. Cell Res 2006, I 6(7):65 I-660. 